\title{
Oxazaborolidines from boracycles through the intramolecular azide insertion $^{1}$
}

\author{
Jorge Ramos ${ }^{2}$ and John A. Soderquist ${ }^{*}$ \\ Department of Chemistry, University of Puerto Rico San Juan, PR 00931-3346 \\ E-mail: jas@janice.uprr.pr
}

Dedicated to Professor Hassner on the occasion of his $\mathbf{7 0}^{\text {th }}$ birthday

(received 11 Jun 01; accepted 07 Oct 01; published on the web 15 Oct 01)

\begin{abstract}
Optically active 2-azido alcohols react with boracycles such as 9-BBN-H and borinane to produce air stable oxazaborolidines, namely 3-oxa-6-aza-2-boratricyclo[5.3.3.0 $\left.{ }^{2,6}\right]$ tridecanes and 10-oxa-7-aza-1-borabicyclo[5.3.0]decanes, respectively. Nopyl azide reacts with 9-BBN-H forming a novel $\mathrm{N}$-substituted-9-aza-10-borabicyclo[3.3.2]decane through a B-C nitrenoid insertion. This intermediate undergoes intramolecular hydroboration at $200{ }^{\circ} \mathrm{C}$ to produce a pinene-derived azaborapentacycle. These compounds were examined in the asymmetric reduction of acetophenone under the conditions employed for CBS-type catalytic processes. The enantioselectivities obtained were very low due to the lack of formation of the oxazaborolidineborane complex, which is essential in orchestrating this process.
\end{abstract}

Keywords: Oxazaborolidines, 9-borabicyclo[3.3.1]nonane, azido alcohols, azidesorganoboranes, boron heterocycles

\section{Introduction}

In recent years, oxazaborolidines have proven to be useful chiral catalysts and reagents in for asymmetric transformations. ${ }^{3}$ Some examples of these oxazaborolidines are illustrated in Scheme 1. Asymmetric processes mediated by these reagents include the asymmetric borane reduction of prochiral ketones catalyzed by $\mathbf{1}$ and $2,{ }^{4}$ the asymmetric addition of alkynyldimethylborane to aldehydes via complexation with $3\left(\mathrm{R}^{1}=\mathrm{CH}_{3}, \mathrm{R}^{2}=\mathrm{H}\right){ }^{5}$ the asymmetric addition of diethylzinc to aldehydes by $3\left(\mathrm{R}^{1}=\mathrm{CH}_{3}\right.$ or $\left.\mathrm{H}, \mathrm{R}^{2}=\mathrm{CH}_{3}\right)$, the asymmetric $\mathrm{Rh}(\mathrm{I})$ catalyzed hydroboration of styrenes by $\mathbf{4},{ }^{7}$ the asymmetric Diels-Alder reaction catalyzed by $5,{ }^{8}$ and the asymmetric aldol reaction of aldehydes and silyl ketene acetals catalyzed by $6 .{ }^{9}$

These oxazaborolidines are prepared by two methods. The $B-H$ derivatives (e.g. $1(\mathrm{R}=\mathrm{H})$, 2, $\left.3\left(\mathrm{R}^{1}=\mathrm{H}, \mathrm{R}^{2}=\mathrm{CH}_{3}\right), 4-6\right)$ are prepared by the reaction of their corresponding $\beta$-amino alcohol 
or $N$-sulfonyl amino acid with $\mathrm{BH}_{3} \cdot \mathrm{L}\left(\mathrm{L}=\right.$ THF or $\left.\mathrm{S}\left(\mathrm{CH}_{3}\right)_{2}\right)$. The $B$-alkyl and -aryl substituted oxazaborolidines (e.g. $1\left(\mathrm{R}=\mathrm{CH}_{3}\right.$ or $\left.\mathrm{Bu}\right), 3\left(\mathrm{R}^{1}=\mathrm{CH}_{3}, \mathrm{R}^{2}=\mathrm{H}\right)$ ) are prepared by the reaction of the amino alcohol or amino acid with the corresponding boronic acid followed by the azeotropic removal of $\mathrm{H}_{2} \mathrm{O}$. The scrupulous exclusion of the water from these reagents and processes is critical because even the partial hydrolysis of the oxazaborolidines can dramatically lower both the yields and enantioselectivities obtained. For example, Merck scientists have encountered this problem in the reduction of prochiral ketones with $(R)$-Me-1. ${ }^{10}$<smiles>[R]B1OC([2H])(c2ccccc2)[C@H]2CCCN12</smiles>

1<smiles>CC1B(N)BO[C@H]1c1ccccc1</smiles>

4<smiles>CC(C)[C@H]1NBBOC1(c1ccccc1)c1ccccc1</smiles>

2<smiles>[R]B1O[C@@H](c2ccccc2)[C@H](c2ccccc2)N1[R]</smiles>

3<smiles>O=C1OB(O)N(Oc2ccccc2)[C@@H]1Cc1c[nH]c2ccccc12</smiles>

5<smiles>COc1ccc(C[C@]2(C)B(O[O+])BOC2=O)cc1OC</smiles>

6

\section{Scheme 1}

Shortly after our discovery of the selective ring B-C bond oxidation with trimethylamine $\mathrm{N}$ oxide in 9-BBN systems, ${ }^{12}$ Brown and Midland reported the analogous process with organic azides and 9-BBN derivatives which give 9,10-azaborabicyclo[3.3.2] decanes. ${ }^{11}$ This process, which was not examined in detail, led us to investigate this process as a novel approach to chiral oxazaborolidines from the reaction of 9-BBN-H 7 with $\beta$-azido alcohols 8 (eq. 1).

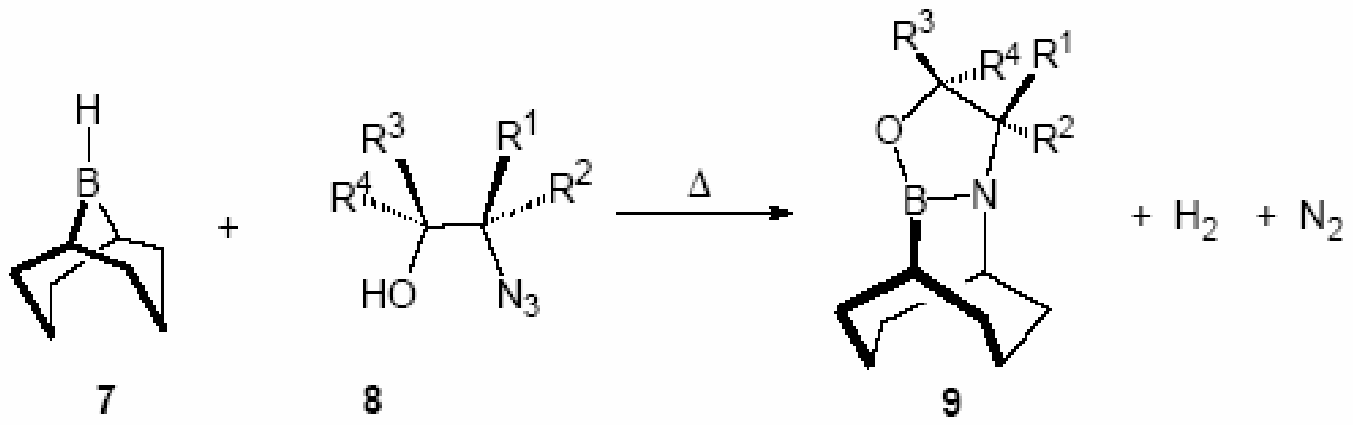




\section{Results and Discussion}

It was found that 7 reacts with 8 to produce the 9-BBN-derived oxazaborolidines 9 (eq. 1). This reaction occurs by the initial formation of $B$-(2-azidoalkoxy)-9- BBNs $10\left({ }^{11} \mathrm{~B}\right.$ NMR: $\delta$ 54.0, Scheme 2) producing $\mathrm{H}_{2}$ gas. This intermediate 10 equilibrates to the cyclic "ate" complex 11 $\left({ }^{11} \mathrm{~B}\right.$ NMR: $\delta$ 7.0), which decomposes to insert the nitrogen moiety into the ring B-C bond, forming $9\left({ }^{11} \mathrm{~B}\right.$ NMR: $\left.\delta 32.0\right)$ with nitrogen gas evolution.

Several new representatives of 9-BBN derived oxazaborolidines 9 were prepared (Table 1). These compounds are thermally stable and are resistant toward oxidation in the open atmosphere. Moreover, they appear to be more resistant to hydrolysis in the open air than are other oxazaborolidines.
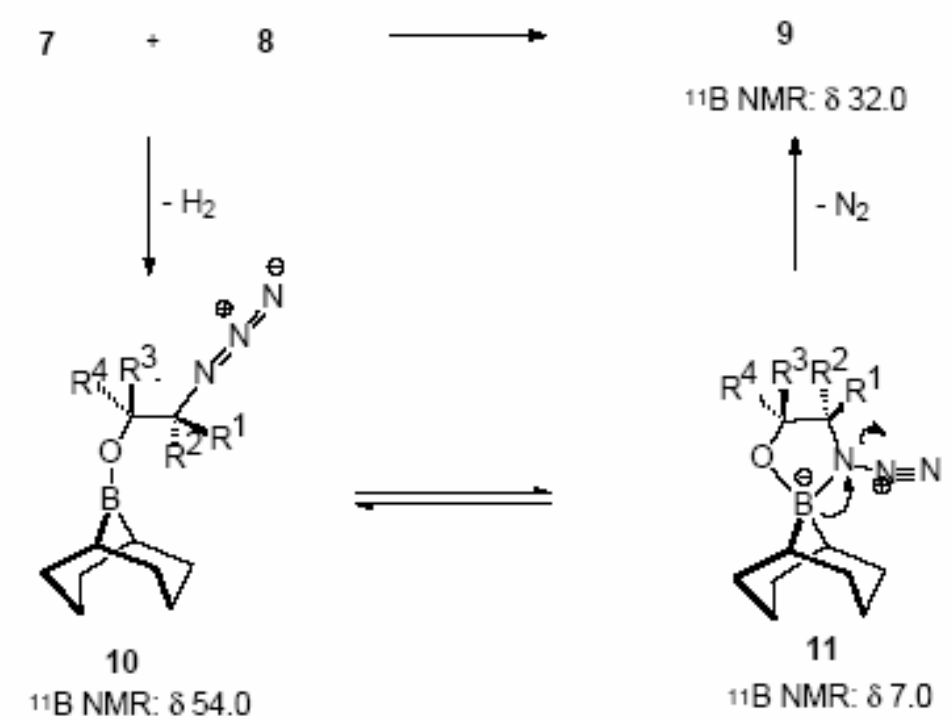

\section{Scheme 2}

In contrast to the boronic acid routes to oxazaborolidines, this new process involves no water by-products. Only hydrogen and nitrogen gases are formed in this reaction (eq. 1). The $\beta$-azido alcohols used for the study were prepared by two well-documented methods. The first method involves the epoxide ring opening reaction with sodium azide in the presence of ammonium chloride. ${ }^{13}$ The second involves a methodology developed by Sharpless where a cyclic sulfate ring is opened by the reaction with sodium azide. ${ }^{14}$ These cyclic sulfates were available from their corresponding diols, which are either commercially available or were prepared through the asymmetric dihydroxylation of the alkene with $\mathrm{OsO}_{4}$. 
Table 1. Oxazaborolidines 9 from 9-BBN-H 7 and $\beta$-azido alcohols 8

\begin{tabular}{cccccc}
\hline Entry & $\mathrm{R}^{1}$ & $\mathrm{R}^{2}$ & $\mathrm{R}^{3}$ & $\mathrm{R}^{4}$ & Yield $^{\mathrm{a}}(\%)$ \\
\hline A & $\mathrm{H}$ & $\mathrm{H}$ & $\mathrm{H}$ & $\mathrm{H}$ & 90 \\
B & $\mathrm{H}$ & $\mathrm{Ph}$ & $\mathrm{H}$ & $\mathrm{H}$ & 91 \\
C & $\mathrm{H}$ & $\mathrm{H}$ & $\mathrm{H}$ & $t-\mathrm{Bu}$ & 97 \\
D & $\mathrm{Ph}$ & $\mathrm{H}$ & $\mathrm{Ph}$ & $\mathrm{H}$ & 54 \\
\hline
\end{tabular}

${ }^{\mathrm{a}}$ Isolated yields

\section{Oxazaborolidines from borinanes}

While less information is available on insertion processes for the borinane ring systems compared to the analogous processes for 9-BBN derivatives, they do appear to be more reactive. For example, the oxidation of $B$-tert-butylborinane with trimethylamine $N$-oxide (TMANO) at $0{ }^{\circ} \mathrm{C}$ proceeds instantaneously forming B-tert-butyl-1,2-oxaborepane. While this process is analogous to the general 9-BBN process, B-tert-butyl-9-BBN itself is inert to TMANO. This difference in reactivity can be understood on the basis of the attack of the borinane by TMANO giving a complex in which the tert-butyl group can occupy an equatorial position with the TMANO occupying an axial position. However, in the 9-BBN system, the related TMANO complex would force the tert-butyl group into an axial position with respect to one of the sixmembered rings, an intermediate which would be expected to be too high in energy to be reached in this process. ${ }^{12}$ In the present case, neither the alcohol nor azide functionalities are large enough to present major steric problems occupying an axial position. Therefore, we expected the borinane process to be more facile, but exhibit analogous behavior to that of the 9-BBN derivatives. 

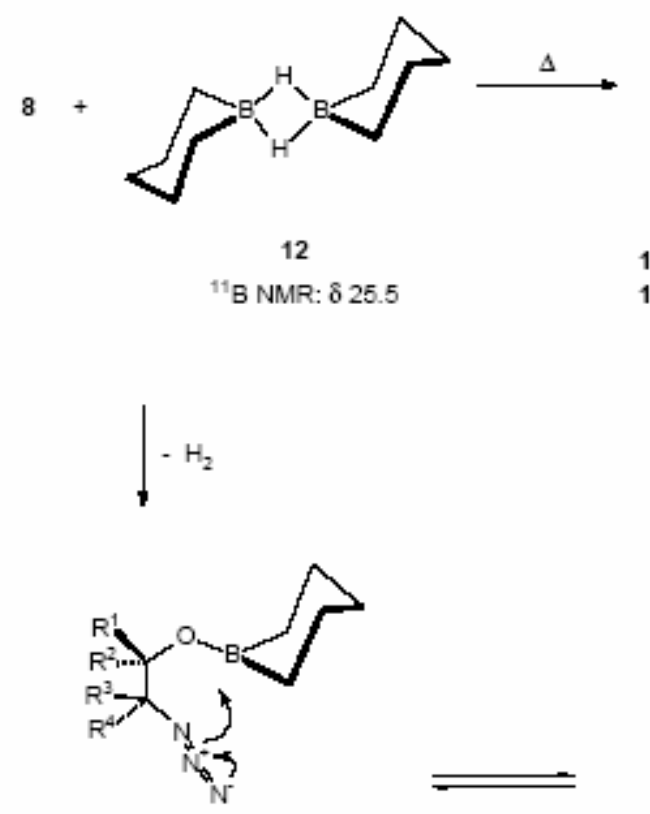

14

${ }^{11} \mathrm{~B}$ NMR: 854.6

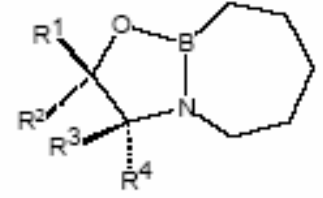

13a: $R^{1}=R^{2}=R^{3}=R^{4}=H ; 66 \%$

13b: $R^{1}=R^{2}=R^{4}=H, R^{3}=P h: 549$

${ }^{11}$ B NMR: 832.6
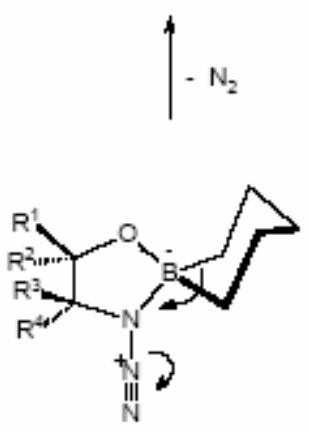

15

${ }^{11}$ B NMR: 87.0

\section{Scheme 3}

The intramolecular azide insertion process was examined with the borinane 12 leading to the smooth formation of the bicyclic oxazaborolidines 13 from 12. The insertion occurs in a manner analogous to that observed for the 9-BBN systems (Scheme 3), where an alkoxyborinane intermediate $14\left({ }^{11} \mathrm{~B}\right.$ NMR: $\delta$ 54.6) is formed with the concomitant evolution of hydrogen gas. This intermediate is in equilibrium with the cyclic complex $15\left({ }^{11} \mathrm{~B}\right.$ NMR: $\left.\delta 7.0\right)$ which collapses to the oxazaborolidine $13\left({ }^{11} \mathrm{~B}\right.$ NMR: 832.6$)$ through a 1,2-alkyl migration from boron to nitrogen producing the 1,2-azaborepane ring and nitrogen gas.

Pinene-derived azaborapentacycles through azide insertion and cyclic hydroboration Midland prepared a series of terpenic azaboracyclohexanes and found that their $\mathrm{BH}_{3}$ complexes reduce prochiral ketones in modest to good enantioselectivities $(60-82 \%) .{ }^{15}$ Evans discovered, in work directed toward the synthesis of echinocandin D, that $\gamma$-olefinic azides react with 9-BBN-H 7 to produce an 9-aza-10-borabicyclo[3.3.2]decane through an intramolecular azide insertion process. $^{16}$ In this $B-\mathrm{R}-9-\mathrm{BBN}$ process, no $\mathrm{B}-\mathrm{R}$ nitrogen insertion was observed, but rather, exclusive nitrogen insertion into a ring $\mathrm{B}-\mathrm{C}$ bond. By contrast, the corresponding dicyclohexylborane adduct did exhibit B-C nitrogen insertion into the B-R moiety leading to the synthesis of pyrrolidines and piperidines. ${ }^{17}$ This process has been applied to the synthesis of the unnatural $(R)$-nicotine by the hydroboration-intramolecular azide insertion process. ${ }^{18}$ It is important to point out for both hydroborating agents, hydroboration was thought to precede the nitrenoid insertion process. We envisaged a new route to 9-BBN-derived terpenic azaborinane 
based upon this methodology. Thus, (-)-nopyl azide 17 was prepared from (-)-nopol 16 in an $84 \%$ overall yield and this was allowed to react with $9-\mathrm{BBN}-\mathrm{H}$. This mixture was ultimately converted to the novel terpene-derived polycycle 19 which contains the 9-aza-10borabicyclo[3.3.2]decane ring system. 19 was prepared from (-)-nopol, 16, through the azide insertion-cyclic hydroboration of (-)-nopyl azide 17 with 9-BBN (Scheme 4).

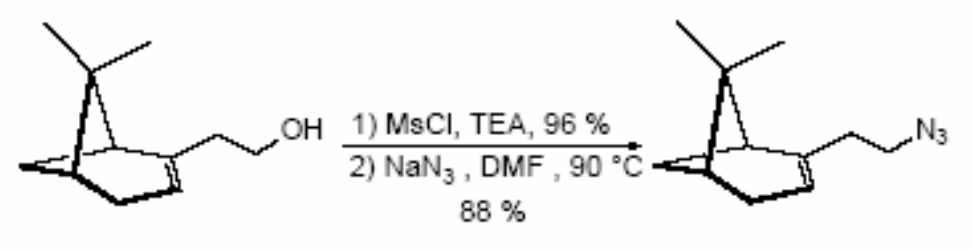

16

17

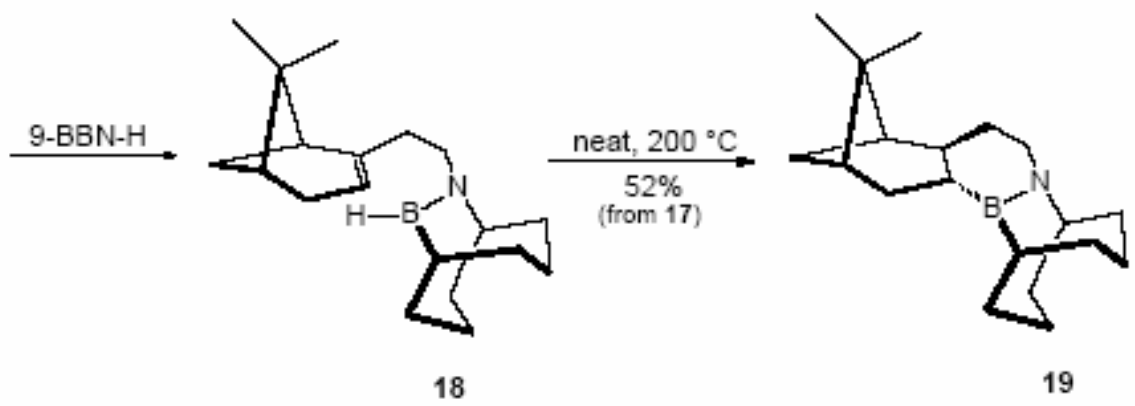

\section{Scheme 4}

Contrary to what was expected, the reaction of $\mathbf{1 7}$ with $\mathbf{7}$ leads to the initial insertion of a nitrogen atom into the 9-BBN ring rather than hydroboration of the $\mathrm{C}=\mathrm{C}$ double bond, forming an $N$-substituted 9-aza-10-borabicyclo[3.3.2]decane $18\left({ }^{11} \mathrm{~B} \mathrm{NMR}: \delta 43.6\right)$, which was isolated in $64 \%$ yield by distillation under high vacuum. Intramolecular hydroboration with neat 18 at $200{ }^{\circ} \mathrm{C}$ led to the formation of $19\left({ }^{11} \mathrm{~B}\right.$ NMR: $\left.\delta 47.0\right)$ in a $50 \%$ overall yield from 17 . The formation of 18 is supported by the presence of the vinylic proton $\left({ }^{1} \mathrm{H} \mathrm{NMR}\left(300 \mathrm{MHz}, \mathrm{CDCl}_{3}\right)\right.$ $\delta 5.22(\mathrm{dd}, J=1.4,1.4 \mathrm{~Hz}, 1 \mathrm{H})$ and carbons $\left({ }^{13} \mathrm{C} \mathrm{NMR}\left(75 \mathrm{MHz}, \mathrm{CDCl}_{3}\right) \delta 117.3\right.$ and 146.1). To further support the presence of the double bond, the $N$-nopyl azaborane 18 was allowed to react with $\mathrm{BH}_{3} \cdot \mathrm{SMe}_{2}$ to form an $\mu$-aminodiborane adduct 20 (eq. 2). These $\mu$-aminodiboranes have been previously reported. ${ }^{19}$ Examples of $B$-substituted $\mu$-aminodiboranes include $\mu$ dimethylaminomethyldiborane $^{20}$ and the 9-BBN-derived 1,1,2,2-bis(cyclooctane-1,5-diyl)- $\mu$ aminodiborane. $^{21}$ 
18

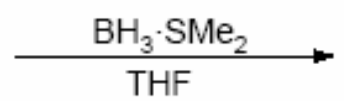

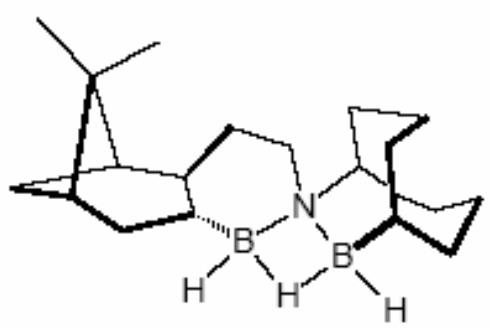

20

\section{A study of the oxazaborolidines 9, 13 and 19 in CBS-type reduction processes}

The 9-BBN derived oxazaborolidines $\mathbf{9 b - d}$, bicyclic oxazaborolidine $\mathbf{1 3 b}$ and azaborapentacycle 19 were tested as asymmetric catalysts and reagents for the asymmetric reduction of acetophenone or propiophenone using $\mathrm{BH}_{3} \cdot \mathrm{THF}$ as the reductant under CBS conditions (eq.3, Table 2). All these reductions are complete in less than $5 \mathrm{~min}$, as observed by $\mathrm{GC}$ and all alcohols are isolated in moderate yields. At lower temperatures the reaction proceeded slower. For example, at $0{ }^{\circ} \mathrm{C}$ with 1 equiv of $9 \mathbf{b}$, the reaction took $6 \mathrm{~h}$ to complete. Unfortunately, very poor enantioselectivities were obtained by using these oxazaborolidines.

To obtain a working model to explain these results and to help in the design of a catalyst that could improve these selectivities, it was necessary to take a deeper look at the mechanism of this reduction. As mentioned previously, ${ }^{4}$ the CBS reduction of prochiral ketones catalyzed by Corey's oxazaborolidine $((R)-B-\mathrm{Me}-1)$ is believed to occur through the formation of the oxazaborolidine- $\mathrm{BH}_{3}$ complex $(R)-B-\mathrm{Me}-\mathbf{1} \cdot \mathrm{BH}_{3}$. This delivers a hydride to the ketone carbon complexed to $(R)-B-\mathrm{Me}-\mathbf{1} \cdot \mathrm{BH}_{3}$ in which the endocyclic boron atom is complexed anti to the large aromatic group. The resulting alkoxyborate complex eventually collapses to the dialkoxyborane, regenerating the catalyst. The borane complex intermediate $(R)-B-\mathrm{Me}-\mathbf{1} \cdot \mathrm{BH}_{3}$, structurally defined by NMR and X-Ray analysis, ${ }^{22}$ is essential to orchestrate this very stereoselective process. The complexation of Corey's CBS B-Me-1 with $\mathrm{BH}_{3} \cdot \mathrm{THF}$ (1:1) was reproduced and reveals that $85 \%$ of $(R)-B-\mathrm{Me}-\mathbf{1} \cdot \mathrm{BH}_{3}$ was formed in equilibrium by ${ }^{11} \mathrm{~B} \mathrm{NMR}$ analysis.<smiles>[R]C(=O)c1ccccc1</smiles>

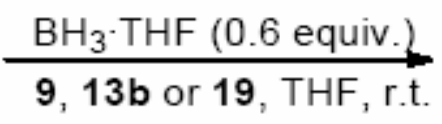<smiles>[R]C(O)c1ccccc1</smiles> 
Table 2. Asymmetric reduction of ketones with $\mathbf{9 ,} \mathbf{1 3 b}$ and 19

\begin{tabular}{cccc}
\hline Heterocycle & $\mathrm{R}$ & Yield $^{\mathrm{a}}(\%)$ & ee $(\%)$, Config. $^{\mathrm{b}}$ \\
\hline 9b & $\mathrm{Et}$ & $64(68) \mathrm{c}$ & $5(12) \mathrm{c}, R_{\mathrm{d}}$ \\
9c & $\mathrm{Me}$ & 66 & $10, R$ \\
9d & $\mathrm{Me}$ & 78 & $15, R$ \\
13b & $\mathrm{Me}$ & 63 & $10, R$ \\
$\mathbf{1 9}$ & $\mathrm{Me}$ & 69 & $19, R_{\mathrm{e}}$ \\
\hline
\end{tabular}

${ }^{a}$ Isolated yields. ${ }^{b}$ Measured by the determination of the diastereomeric composition of their MTPA (Mosher) esters. ${ }^{\mathrm{c}}$ Yield and ee by using 1 equiv of $\mathbf{9 b}$ at $0{ }^{\circ} \mathrm{C} .{ }^{\mathrm{d}}$ Determined by comparing the sign of rotation with the obtained in the literature. ${ }^{\mathrm{e}}$ The reaction was carried out by using 1 equiv of 19 at $0{ }^{\circ} \mathrm{C}$.

Values of $\mathrm{K}=73 \mathrm{M}^{-1}$ and $\Delta \mathrm{G}^{\circ}=-2.53 \mathrm{kcal} / \mathrm{mol}$ were calculated from this data. The asymmetric reduction of acetophenone with $(S)-B-M e-1$ was performed under catalytic conditions where $(R)$-sec-phenethyl alcohol was obtained in $94 \%$ ee in agreement with Corey's results. $^{4 \mathrm{e}}$

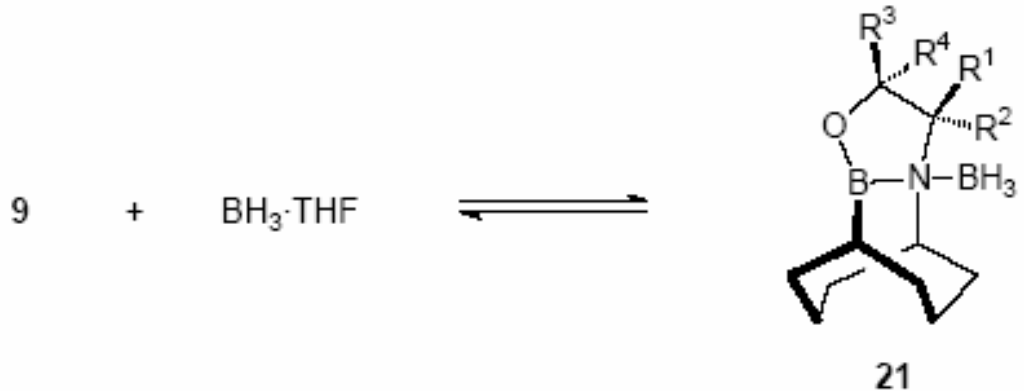

In contrast, the $\mathrm{BH}_{3}$ complexation experiment with the 9-BBN-derived oxazaborolidines 9 and 19 revealed that neither of these boron-ring systems produced significant amounts of borane complexes analogous to 21 (eq. 4). For example, in 9a and 9c less than 5\% of 21 were observed to form. MMX calculations suggest that the nitrogen atom in $\mathbf{9}$ adapts a nearly planar geometry. In addition, the methylene carbons of the 9-aza-10-borabicyclo[3.3.2]decyl (ABBD) system imparts a steric interaction with the approaching $\mathrm{BH}_{3}$ species. This methylene group makes this nitrogen more hindered toward borane complexation. These findings are analogous to other amine-borane complexes, where their complex stability and hence high reactivity toward hydroboration and carbonyl reduction is influenced by these steric effects. ${ }^{23}$ In addition, when propiophenone is added to either oxazaborolidines $(R)-B-\mathrm{Me}-\mathbf{1}$ or $\mathbf{9 b}$, no oxazaborolidine-ketone complexed was observed to form by ${ }^{11} \mathrm{~B}$ and ${ }^{13} \mathrm{C}$ NMR indicating the weak Lewis acidity of these oxazaborolidines. The Corey's oxazaborolidine-borane complex $B-\mathrm{Me}-\mathbf{1} \cdot \mathrm{BH}_{3}$ contains a more Lewis acidic boron than the uncomplexed catalyst $B$-Me-1. These species are possibly more reactive to ketone complexation than $B$-Me-1. Even though the reduction of ketones catalyzed by 9 are complete in $5 \mathrm{~min}$, poor enantioselectivity in this process due to the 
oxazaborolidine-borane complex intermediate is observed. This lack of borane complexation by these 9-BBN-derived cyclic systems $\mathbf{9}$ explains why they do not function as effective asymmetric catalysts in the reduction of prochiral ketones.

$$
13 \mathrm{a}+\mathrm{BH}_{3} \cdot \mathrm{THF} \frac{\mathrm{K}=3.3 \mathrm{M}^{-1}}{\Delta \mathrm{G}^{\circ}=-0.71 \mathrm{Kcal} / \mathrm{mol}}
$$

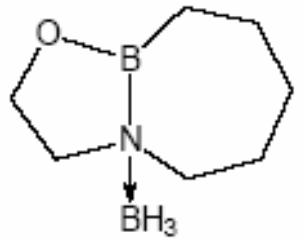

22

Bicyclic oxazaborolidine 13a was evaluated in the borane complexation process where 50\% of 22 complex was formed upon the addition of $1 \mathrm{~mol} /$ eq. of $\mathrm{BH}_{3} \cdot \mathrm{THF}$ as observed by ${ }^{11} \mathrm{~B}$ NMR (eq. 5). From this, $\mathrm{K}=3.3 \mathrm{M}^{-1}$ and $\Delta \mathrm{G}^{\circ}=-0.71 \mathrm{Kcal} / \mathrm{mol}$. Unfortunately, the chiral oxazaborolidine $\mathbf{1 3 b}$ produced only $10 \%$ ee in the sec-phenethyl alcohol from the CBS-type reduction of acetophenone. From the above, the greater basicity of the nitrogen atom and other structural features present in the CBS catalysts are critical to their success. The systems examined herein lack the ability to simultaneously complex borane and effectively direct the process. Further studies with these interesting new boron heterocycles in other asymmetric processes are underway.

\section{Experimental Section}

General Procedures. All experiments were carried out in pre-dried glassware $\left(1 \mathrm{~h}, 250{ }^{\circ} \mathrm{C}\right)$ under nitrogen atmosphere. Standard handling techniques for air-sensitive compounds were employed through out this study. NMR spectra were obtained on a General Electric QE-300, a General Electric GN-300, a Bruker Advance DPX-300 and / or a Bruker Advance DRX-500 spectrometers. ${ }^{1} \mathrm{H},{ }^{13} \mathrm{C}$ and ${ }^{11} \mathrm{~B}$ NMR were recorded in $\mathrm{CDCl}_{3}$ or $\mathrm{C}_{6} \mathrm{D}_{6}$, unless otherwise used, and the chemical shifts were expressed in ppm relative to $\mathrm{CDCl}_{3}\left(7.26\right.$ and $77.0 \mathrm{ppm}$ in ${ }^{1} \mathrm{H}$ and ${ }^{13} \mathrm{C}$ NMR, respectively) or $\mathrm{C}_{6} \mathrm{D}_{6}$ (7.15 and $128.0 \mathrm{ppm}$ in ${ }^{1} \mathrm{H}$ and ${ }^{13} \mathrm{C} \mathrm{NMR}$, respectively) as the internal standard. Multiplicity assignments and sequence in ${ }^{13} \mathrm{C}$ NMR were made with the aid of DEPT and HETCOR experiments. ${ }^{1} \mathrm{H}$ NMR assignments were carried out with the aid of ${ }^{1} \mathrm{H}-{ }^{1} \mathrm{H}$ COSY experiment. Infrared spectra were obtained on a Nicolet Magna IR-750, a Perkin-Elmer 281 or a Nicolet Series 6000 FT-IR spectrophotometers. Mass spectral data were obtained with a Hewlett-Packard 5995A GC/MS spectrometer $(70 \mathrm{eV})$. High resolution mass spectral data were obtained with a Micromass VG AutoSpec magnetic sector mass spectrometer (70 eV). Gas chromatographic analyses were performed with a Perkin-Elmer 8320 capillary or a Perkin-Elmer Autosystem XL gas chromatograph using $30 \mathrm{~m}$ X $0.25 \mathrm{~mm}$ I.D. 20\% SE-30 vitreous silica open tubular columns. Optical rotation data were obtained using a Perkin-Elmer 243B Polarimeter. 
Elemental analyses were performed by Atlantic Microlabs, Norcross, Georgia.

\section{Preparation of azido alcohols 8}

2-Azidoethanol 8a was prepared from 2-chloroethanol by the reaction with $\mathrm{NaN}_{3}{ }^{25}(S)-(+)-2$ azido-2-phenylethanol $\mathbf{8 b}^{26}$ was prepared from $(R)-(+)$-styrene oxide through the ring opening reaction with $\mathrm{NaN}_{3} / \mathrm{NH}_{4} \mathrm{Cl}{ }^{13}(2 R)-(+)-3,3$-Dimethyl-1-azido-2-butanol 8c ${ }^{27}$ and $(1 R, 2 S)-(+)-1,2-$ Diphenyl-2-azidoethanol $\mathbf{8} \mathbf{d}^{28}$ were prepared from $(2 R)-(-)-3,3-d i m e t h y l b u t a n e-1,2-$ diol $^{29}$ and $(R, R)-(+)$-hydrobenzoin, ${ }^{30}$ respectively, through the reaction of their corresponding cyclic sulfates with $\mathrm{NaN}_{3}$. ${ }^{14,31}$

3-Oxa-6-aza-2-bora tricyclo[5.3.3.0 $\left.{ }^{2,6}\right]$ tridecane (9a). Into a 2-necked-round bottom flask equipped with a reflux condenser and containing $7(1.83 \mathrm{~g}, 15.0 \mathrm{mmol})$ in hexane $(15.0 \mathrm{~mL})$ was added $8 \mathrm{a}(1.31 \mathrm{~g}, 15.0 \mathrm{mmol})$. The reaction mixture was stirred at reflux temperature. After $1 \mathrm{~h}$, an aliquot was taken, and by ${ }^{11} \mathrm{~B}$ NMR analysis indicated the presence of B-(2-azidoethoxy)-9BBN intermediate 10 ( ${ }^{11} \mathrm{~B}$ NMR $\left.\delta 57.4,40 \%\right)$, oxazaborolidine 9a $\left({ }^{11} \mathrm{~B}\right.$ NMR $\left.\delta 36.2,40 \%\right)$ and the $\beta$-azidoethoxy cyclic "ate" complex $11\left({ }^{11} \mathrm{~B}\right.$ NMR $\left.\delta 7.0,20 \%\right)$. After $12 \mathrm{~h}$, when the reaction was complete (monitored by ${ }^{11} \mathrm{~B} \mathrm{NMR}$ ), the solvent was removed by vacuum and the residue was distilled to obtain $2.42 \mathrm{~g}\left(90 \%\right.$, bp $104-105{ }^{\circ} \mathrm{C} / 0.65$ Torr) of 9a. ${ }^{1} \mathrm{H}-\mathrm{NMR}(300 \mathrm{MHz}$, $\left.\mathrm{CDCl}_{3}\right): \delta 1.37-1.43(\mathrm{~m}, 5 \mathrm{H}), 1.47-1.65(\mathrm{~m}, 4 \mathrm{H}), 3.20$ (broad m, $\left.1 \mathrm{H}\right), 3.25(\mathrm{t}, J=7.8 \mathrm{~Hz}, 2 \mathrm{H})$, $4.17(\mathrm{t}, J=7.5 \mathrm{~Hz}, 2 \mathrm{H}) ;{ }^{13} \mathrm{C}-\mathrm{NMR}\left(75 \mathrm{MHz}, \mathrm{CDCl}_{3}\right) \delta 17.1$ (C 1), 22.2 (C 9, C 12), 26.7 (C 10, C 11), 30.6 (C 8, C 13), 49.8 (C 5), 56.4 (C 7), 66.9 (C 4); ${ }^{11} \mathrm{~B}-\mathrm{NMR}$ (96 MHz, $\mathrm{CDCl}_{3}$ ): $\delta 36.1$ (87 \%), 9.76 (dimeric 9a, 13\%); MS: m/z (rel. abundance) $179\left(\mathrm{M}^{+}, 7\right), 178$ (3), 150 (100), 136, (30), 122 (70), 67 (25), 54 (30). HRMS (EI) exact mass calc. for $\mathrm{C}_{10} \mathrm{H}_{18} \mathrm{BNO} 179.1481$, found 179.1484 .

(5S)-(+)-Phenyl-3-oxa-6-aza-2-boratricyclo[5.3.3.0 ${ }^{2,6}$ tridecane (9b). Into a 2-necked-round bottom flask equipped with a reflux condenser and containing 7 (3.66 g , $30.0 \mathrm{mmol})$ in hexane $(45.0 \mathrm{~mL})$ was added $\mathbf{8 b}(4.89 \mathrm{~g}, 30.0 \mathrm{mmol})$. The reaction mixture was stirred at $25{ }^{\circ} \mathrm{C}$ for $2 \mathrm{~h}$ and then at reflux temperature for $72 \mathrm{~h}$. The solvent was removed by vacuum and the residue was distilled to obtain $6.98 \mathrm{~g}\left(91 \%\right.$, bp $145{ }^{\circ} \mathrm{C} / 0.04$ Torr) of $9 b$. $[\alpha]^{25}{ }_{\mathrm{D}}+125^{\circ}$ (c 1.7, $\left.n-\mathrm{C}_{6} \mathrm{H}_{14}\right)$. ${ }^{1} \mathrm{H}-\mathrm{NMR}\left(300 \mathrm{MHz}, \mathrm{C}_{6} \mathrm{D}_{6}\right): \delta$ 1.24-1.64 (m, $\left.7 \mathrm{H}\right), 1.75-1.90(\mathrm{~m}, 6 \mathrm{H}), 2.90(\mathrm{~s}, 1 \mathrm{H}), 3.97$ (dd, $J=$ 7.8, 7.8 Hz, $1 \mathrm{H}), 4.35$ (dd, J=7.8, 7.8 Hz, $1 \mathrm{H}), 4.42$ (dd, J=7.8, 7.8 Hz, $1 \mathrm{H}), 7.20$ (m $5 \mathrm{H}$ ); ${ }^{13} \mathrm{C}-\mathrm{NMR}\left(75 \mathrm{MHz}, \mathrm{C}_{6} \mathrm{D}_{6}\right.$ ) $\delta 17.2$ (C 1), 22.4 (C 12), 22.9 (C 9), 26.4 (C 11), 26.5 (C 10), 29.9 (C 13), 31.4 (C 8 ), 47.4 (C 7), 65.0 (C 5), 75.5 (C 4), 127.2, 127.4, 128.4, 142.5 (o, p, m, i of Ph ring) ; ${ }^{11} \mathrm{~B}-\mathrm{NMR}\left(96 \mathrm{MHz}, \mathrm{CDCl}_{3}\right) \delta 37.0$; IR (TF) 2900, 1950, 1875, 1810, 1750, 1700 (overtone mono subst. Ph) $1600 \mathrm{~cm}^{-1}$; MS: m/z (rel. abundance) $255\left(\mathrm{M}^{+}, 46\right), 226(100), 212$ (25), 198 (25), 146 (11), 115 (5), 105 (6), 95 (6), 77 (5), 59 (6). HRMS (EI) exact mass calc. for $\mathrm{C}_{16} \mathrm{H}_{22} \mathrm{BNO} 255.1794$, found 255.1777 .

(4R)-(+)-(1,1-Dimethylethyl)-3-oxa-6-aza-2-boratricyclo[5.3.3.0 $\left.{ }^{2,6}\right]$ tridecane (9c). Into a 2necked-round bottom flask equipped with a reflux condenser containing 7 (0.34 g , $2.80 \mathrm{mmol})$ in hexane $(3.0 \mathrm{~mL})$ was added $8 \mathrm{c}(0.40 \mathrm{~g}, 2.80 \mathrm{mmol})$. The reaction mixture was stirred at reflux temperature for $18 \mathrm{~h}$. The solvent was removed under vacuum and the residue was distilled to 
obtain $0.64 \mathrm{~g}\left(97 \%\right.$, bp $93{ }^{\circ} \mathrm{C} / 0.1$ Torr) of $9 \mathrm{c} .[\alpha]^{25}{ }_{\mathrm{D}}+7.7^{\circ}$ (c 3.0, $\left.n-\mathrm{C}_{6} \mathrm{H}_{14}\right) .{ }^{1} \mathrm{H}-\mathrm{NMR}(300 \mathrm{MHz}$, $\left.\mathrm{C}_{6} \mathrm{D}_{6}\right): \delta 0.90(\mathrm{~s}, 9 \mathrm{H}), 1.30-1.51(\mathrm{~m}, 5 \mathrm{H}), 1.53-1.75(\mathrm{~m}, 8 \mathrm{H}), 2.89(\mathrm{~d}, J=8.4 \mathrm{~Hz}, 2 \mathrm{H}), 2.94-$ $3.00(\mathrm{~m}, 1 \mathrm{H}), 4.05$ (t, $J=8.4 \mathrm{~Hz}, 1 \mathrm{H}) ;{ }^{13} \mathrm{CNMR}\left(75 \mathrm{MHz}, \mathrm{C}_{6} \mathrm{D}_{6}\right) \delta 18.0$ (C 1), 23.1 (C 12), 23.2 (C 9), 27.1 (C 11), 27.1 (C 10), 30.4 (C 13), 31.7 (C 8), 50.2 (C 7), $25.1\left(\left(\mathrm{CH}_{3}\right)_{3} \mathrm{C}\right), 34.1$ $\left(\left(\mathrm{CH}_{3}\right)_{3} \mathrm{C}\right), 51.3$ (C 5), 86.0 (C 4); ${ }^{11} \mathrm{~B}-\mathrm{NMR}\left(96 \mathrm{MHz}, \mathrm{CDCl}_{3}\right) \delta 32.1 . \mathrm{MS}: \mathrm{m} / \mathrm{z}$ (rel. abundance) $235\left(\mathrm{M}^{+}, 17\right), 206$ (100), 192 (17), 178 (54), 67 (11), 55 (19). HRMS (EI) exact mass calc. for $\mathrm{C}_{14} \mathrm{H}_{26} \mathrm{BNO} 235.2107$, found 235.2081.

(4R,5S)-(+)-Diphenyl-3-oxa-6-aza-2-boratricyclo[5.3.3.0 $\left.{ }^{2,6}\right]$ tridecane (9d). Into a 2-neckedround bottom flask equipped with a reflux condenser containing $7(0.61 \mathrm{~g}, 5.0 \mathrm{mmol})$ in THF $(10.0 \mathrm{~mL})$ was added $8 \mathrm{~d}(1.20 \mathrm{~g}, 5.0 \mathrm{mmol})$. The reaction mixture was stirred at reflux temperature for $72 \mathrm{~h}$. The solvent was removed under vacuum and the residue was chromatographed trough silica (eluting with $10 \%$ ether in pentane). The elutant was concentrated to obtain $0.90 \mathrm{~g}(54 \%)$ of 9 d. $[\alpha]^{25}{ }_{\mathrm{D}}+121^{\circ}$ (c 1.4, $\left.n-\mathrm{C}_{6} \mathrm{H}_{14}\right) .{ }^{1} \mathrm{HNMR}\left(300 \mathrm{MHz}, \mathrm{C}_{6} \mathrm{D}_{6}\right): \delta 1.22(\mathrm{~s}$, $1 \mathrm{H}), 1.39-1.69(\mathrm{~m}, 5 \mathrm{H}), 1.71-2.00(\mathrm{~m}, 7 \mathrm{H}), 3.02$ (broad m, $1 \mathrm{H}), 5.04(\mathrm{~d}, J=9.0 \mathrm{~Hz}, 1 \mathrm{H})$, $5.77(\mathrm{~d}, J=9.0 \mathrm{~Hz}, 1 \mathrm{H}), 6.93-7.12(\mathrm{~m}, 10 \mathrm{H}) ;{ }^{13} \mathrm{C}-\mathrm{NMR}\left(75 \mathrm{MHz}, \mathrm{C}_{6} \mathrm{D}_{6}\right) \delta 18.5(\mathrm{C} 1), 22.7(\mathrm{C}$ 12), 23.0 (C 9), 26.1 (C 11), 26.8 (C 10), 29.9 (C 13), 31.7 (C 8), 47.9 (C 7), 69.7 (C 5), 84.2 (C 4), 126.4, 126.6, 126.8, 139.4 (o, $m, p, i$ of $\mathrm{Ph}$ ring at $\mathrm{C} 4), 127.2,127.5,128.4,138.8$ (o, $p, \mathrm{~m}, i$ of $\mathrm{Ph}$ ring at $\mathrm{C} \mathrm{5}) ;{ }^{11} \mathrm{BNMR}\left(96 \mathrm{MHz}, \mathrm{CDCl}_{3}\right) \delta 37.1$. HRMS (EI) exact mass calc. for $\mathrm{C}_{22} \mathrm{H}_{26} \mathrm{BNO} 331.2107$, found 331.2099.

10-Oxa-7-aza-1-borabicyclo[5.3.0]decane (13a). Into a 2-necked round-bottomed flask equipped with a reflux condenser containing $1(0.36,4.4 \mathrm{mmol})$ in hexane $(10.0 \mathrm{~mL})$ was added 8a $(0.38 \mathrm{~g}, 4.4 \mathrm{mmol})$. The reaction mixture was allowed to be stirred at reflux temperature. After $1 \mathrm{~h}$, an aliquot was taken for ${ }^{11} \mathrm{~B}$ NMR analysis revealing the presence of a $\beta$ azidoalkoxyborane intermediate $(\mathbf{1 4}, \delta 54.6)$, "ate" complex $15(\delta 7.0)$ and the product oxazaborolidine 13a $(\delta 32.6)$. The reaction mixture was stirred for $60 \mathrm{~h}$ at reflux temperature. The solvent was removed in vacuo and the residue was fractionally distilled to obtain $0.40 \mathrm{~g}$ (66\%, bp $93{ }^{\circ} \mathrm{C} / 0.7$ Torr) of 13a. ${ }^{1} \mathrm{H}$ NMR (300 MHz, $\left.\mathrm{CDCl}_{3}\right): \delta 0.81-0.93(\mathrm{~m}, 2 \mathrm{H}), 1.19-1.29$ $(\mathrm{m}, 2 \mathrm{H}), 1.51($ broad s, $2 \mathrm{H}), 1.64-1.65$ (broad s, $2 \mathrm{H}), 3.33(\mathrm{t}, J=4.8 \mathrm{~Hz}, 2 \mathrm{H}), 3.76(\mathrm{t}, J=6.7$ $\mathrm{Hz}, 2 \mathrm{H}), 3.98(\mathrm{t}, J=9.0 \mathrm{~Hz}, 2 \mathrm{H}) ;{ }^{13} \mathrm{C} \mathrm{NMR}\left(75 \mathrm{MHz}, \mathrm{CDCl}_{3}\right) \delta 14.0$ (C 2), 22.8 (C 3), 31.4 (C 4), 32.0 (C 5), 52.1 (C 6), 61.3 (C 8), 67.2 (C 9); ${ }^{11} \mathrm{~B}-\mathrm{NMR}\left(96 \mathrm{MHz}, \mathrm{CDCl}_{3}\right.$ ) $\delta$ 32.6.

(10S)-Phenyl-10-oxa-7-aza-1-borabicyclo[5.3.0]decane (13b). Into a 2-necked roundbottomed flask equipped with a reflux condenser containing $B$-methoxy-borinane (1.12 g, 10.0 $\mathrm{mmol})$ in monoglyme $(10.0 \mathrm{~mL})$ was added $\mathrm{BH}_{3} \cdot \mathrm{SMe}_{2}(0.5 \mathrm{~mL}(10.0 \mathrm{M}), 5.0 \mathrm{mmol})$. The resulting mixture was stirred at reflux temperature for $2 \mathrm{~h}$. The reflux condenser was replaced with a short-path distillation apparatus and the reaction mixture was distilled under $\mathrm{N}_{2}$ until a distillation temperature of $85{ }^{\circ} \mathrm{C}$ was reached, indicating the distillation of pure monoglyme. The mixture was cooled down to $25^{\circ} \mathrm{C}$ and fresh monoglyme $(10.0 \mathrm{~mL})$ was added. The distillation apparatus was exchanged for a reflux condenser and $\mathbf{8 b}$ (1.30 g, $8.0 \mathrm{mmol})$ was added. The reaction mixture was stirred for $72 \mathrm{~h}$ at reflux temperature. The solvent was removed in vacuo and the residue was fractionally distilled to obtain $0.92 \mathrm{~g}(54 \%)$ of $\mathbf{1 3 b}$. 
${ }^{1} \mathrm{H}$ NMR (300 MHZ, $\left.\mathrm{CDCl}_{3}\right): \delta 0.80-1.00(\mathrm{~m}, 1 \mathrm{H}), 1.07-1.10(\mathrm{~m}, 1 \mathrm{H}), 1.18-1.24(\mathrm{~m}, 1 \mathrm{H})$, $1.41-1.56(\mathrm{~m}, 5 \mathrm{H}), 2.55$ (broad s, $2 \mathrm{H}), 3.89(\mathrm{dd}, J=6.6,9.0 \mathrm{~Hz}, 1 \mathrm{H}), 4.11(\mathrm{dd}, J=6.6,6.6 \mathrm{~Hz}$, $1 \mathrm{H}), 4.33(\mathrm{dd}, J=9.0,9.0 \mathrm{~Hz}, 1 \mathrm{H}), 7.10-7.15(\mathrm{~m}, 5 \mathrm{H}) ;{ }^{13} \mathrm{C} \mathrm{NMR}\left(75 \mathrm{MHz}, \mathrm{CDCl}_{3}\right) \delta 12.5(\mathrm{C}$ 6), 25.0 (C 4), 31.1 (C 5), 31.4 (C 3), 45.8 (C 2), 67.5 (C 10), 74.8 (C 9), 127.2, 127.4, 128.9, 143.5 (o, p, $m$, i of $\mathrm{Ph}$ ring); ${ }^{11} \mathrm{~B}-\mathrm{NMR}\left(96 \mathrm{MHz}, \mathrm{CDCl}_{3}\right) \delta 32.5$.

(1R,5S)-(-)-2-(2-Azidoethyl)-7,7-dimethylbicyclo[3.1.1]hept-2-ene ((-)-Nopyl azide, (17)). Into a round bottom flask containing $16(13.9,83.6 \mathrm{mmol})$ and triethylamine $(13.5 \mathrm{~g}, 133 \mathrm{mmol})$ in $\mathrm{CH}_{2} \mathrm{Cl}_{2}(400 \mathrm{~mL})$ at $0{ }^{\circ} \mathrm{C}$ was added methanesulfonyl chloride (14.3 g, $\left.124.8 \mathrm{mmol}\right)$ dropwise. The reaction mixture was warmed to room temperature slowly and stirred overnight and transferred into a separatory funnel with ice water. The aqueous phase was separated and the organic phase was washed with ice water $(5 \mathrm{X} 200 \mathrm{~mL})$. The organic phase was dried over magnesium sulfate, decanted and concentrated to give $19.5 \mathrm{~g}(96 \%)$ of the crude nopyl mesylate. ${ }^{1} \mathrm{H}-\mathrm{NMR}\left(300 \mathrm{MHz}, \mathrm{CDCl}_{3}\right) \delta 0.79(\mathrm{~s}, 3 \mathrm{H}), 1.11(\mathrm{~d}, \mathrm{~J}=8.6 \mathrm{~Hz}, 1 \mathrm{H}), 1.24(\mathrm{~s}, 3 \mathrm{H}), 2.02-2.07$ (m, $2 \mathrm{H}), 2.18-2.20(\mathrm{~m}, 1 \mathrm{H}), 2.31-2.39(\mathrm{~m}, 3 \mathrm{H}), 2.95(\mathrm{~s}, 3 \mathrm{H}), 4.14(\mathrm{td}, J=7.1,1.1 \mathrm{~Hz}, 2 \mathrm{H})$, 5.56 (broad m, $1 \mathrm{H}) ;{ }^{13} \mathrm{C}-\mathrm{NMR}\left(75 \mathrm{MHz}, \mathrm{CDCl}_{3}\right) \delta 20.9$ (C 8), 26.0 (C 9), 31.3 (C 6), $36.1\left(\mathrm{CH}_{2}\right.$ $\mathrm{CH}_{2} \mathrm{OMs}$ ), $37.1\left(\mathrm{CH}_{3} \mathrm{SO}_{3}\right), 37.8$ (C 7), 40.4 (C 5), 45.4 (C 1), 67.8 ( $\left.\mathrm{CH}_{2} \mathrm{OMs}\right), 1196$ (C 3), 142.4 (C 2). Note!: This mesylate decomposes explosively upon heating, and was used without further purification for the next reaction. This nopyl mesylate $(19.3 \mathrm{~g}, 79 \mathrm{mmol})$ in DMF $(200 \mathrm{~mL})$ was added to a $1 \mathrm{~L}$ 2-neck round-bottomed flask containing sodium azide (39.7 g, $611 \mathrm{mmol})$. The reaction slurry was stirred and heated to $\sim 90{ }^{\circ} \mathrm{C}$ for $1 \mathrm{~h}$ (followed by GC). After the reaction was complete, the mixture was cooled to room temperature and pentane $(500 \mathrm{~mL})$ and water $(200 \mathrm{~mL})$ were added. The aqueous phase was separated and the organic phase was washed with water (5 X $200 \mathrm{~mL})$. The organic phase was dried over magnesium sulfate, decanted and concentrated. This concentrate was flash chromatographed over silica gel (eluting with pentane), concentrated and distilled to give $13.3 \mathrm{~g}\left(88 \%\right.$, bp $70{ }^{\circ} \mathrm{C} / 0.25$ Torr) of 17 . $[\alpha]^{25}{ }_{\mathrm{D}}-47^{\circ}$ (c 14.7 , $\left.\mathrm{CCl}_{4}\right) .{ }^{1} \mathrm{H}-\mathrm{NMR}\left(300 \mathrm{MHz}, \mathrm{CDCl}_{3}\right) \delta 0.86(\mathrm{~s}, 3 \mathrm{H}), 1.16(\mathrm{~d}, J=8.6 \mathrm{~Hz}, 1 \mathrm{H}), 1.28(\mathrm{~s}, 3 \mathrm{H}), 2.01$ $(\mathrm{td}, J=5.6,1.4 \mathrm{~Hz}, 1 \mathrm{H}), 2.07-2.11(\mathrm{~m}, 1 \mathrm{H}), 2.22-2.27(\mathrm{~m}, 4 \mathrm{H}), 2.37(\mathrm{dt}, J=8.6,5.7 \mathrm{~Hz}, 1 \mathrm{H})$, $3.25(\mathrm{ddt}, J=16.4,12.7,7.1 \mathrm{~Hz}, 2 \mathrm{H}), 5.32(\mathrm{dd}, J=2.8,1.4 \mathrm{~Hz}, 1 \mathrm{H}) ;{ }^{13} \mathrm{C}-\mathrm{NMR}(75 \mathrm{MHz}$, $\mathrm{CDCl}_{3}$ ) $\delta 21.1$ (C 9), 26.2 (C 8), 31.3 (C 4), 31.6 (C 6), 35.9 (C 7), $38.0\left(\mathrm{CH}_{2} \mathrm{CH}_{2} \mathrm{~N}_{3}\right), 40.7$ (C 5), 45.6 (C 1), $49.3\left(\mathrm{CH}_{2} \mathrm{~N}_{3}\right), 118.9$ (C 3), 144.2 (C 2); IR(TF) $2090 \mathrm{~cm}^{-1}$ (-N3); MS m/z (rel. abundance) $162\left(\mathrm{M}^{+}-29,6\right), 148$ (20), 120 (34), 91 (100), 77 (12), 67 (23); Anal. calc. for $\mathrm{C}_{11} \mathrm{H}_{17} \mathrm{~N}_{3}$ : C, 69.07; H, 8.96; found: C, 68.96; H, 9.03.

(1R,5S)-2-(2-(9-Aza-10-borabicyclo[3.3.2]dec-9-yl)ethyl)-7,7-dimethylbicyclo[3.1.1]hept-2-

ene (18). Into a round bottomed flask containing $7(6.10 \mathrm{~g}, 50.0 \mathrm{mmol})$ in hexane $(50 \mathrm{~mL})$ at $0{ }^{\circ} \mathrm{C}$ was added $17(9.55 \mathrm{~g}, 50.0 \mathrm{mmol})$. The reaction mixture was stirred at $0{ }^{\circ} \mathrm{C}$ for $1 \mathrm{~h}$ and warmed to $25{ }^{\circ} \mathrm{C}$ and stirred for $12 \mathrm{~h}$ at this temperature. Concentration and distillation under high vacuum gave $9.6 \mathrm{~g}\left(64 \%\right.$, bp $\left.160{ }^{\circ} \mathrm{C} / 0.1 \mathrm{Torr}\right)$ of $18 .{ }^{1} \mathrm{H}-\mathrm{NMR}\left(300 \mathrm{MHz}, \mathrm{CDCl}_{3}\right): \delta 0.83$ $(\mathrm{s}, 3 \mathrm{H}), 1.14(\mathrm{~d}, J=8.4 \mathrm{~Hz}, 1 \mathrm{H}), 1.27(\mathrm{~s}, 3 \mathrm{H}), 1.36-1.48(\mathrm{~m}, 4 \mathrm{H}), 1.53-1.59$ (br m, $4 \mathrm{H})$, 1.60-1.64 (m, $4 \mathrm{H}), 1.70-1.80(\mathrm{~m}, 3 \mathrm{H}), 2.02-2.13(\mathrm{~m}, 4 \mathrm{H}), 2.19-2.22(\mathrm{~m}, 1 \mathrm{H}), 2.33-2.36(\mathrm{~m}$, $1 \mathrm{H}), 3.06-3.12$ (m , $2 \mathrm{H}), 3.24$ (br m, $1 \mathrm{H}), 5.22$ (dd , $J=1.4,1.4 \mathrm{~Hz}, 1 \mathrm{H}) ;{ }^{13} \mathrm{C}-\mathrm{NMR}(75 \mathrm{MHz}$, 
$\mathrm{CDCl}_{3}$ ) $\delta 22.0,23.2,26.6,31.2,57.3$ (ABBD ring), 21.2 (C 8), 26.3 (C 9), 31.3 (C 4), 31.6 (C 6), 38.0 (C 7), 39.2 (C 10), 40.8 (C 5), 45.8 (C 1), 57.9 (C 11), 117.3 (C 3), 146.1 (C 2) ; ${ }^{11} \mathrm{~B}-\mathrm{NMR}$ $\left(96 \mathrm{MHz}, \mathrm{CDCl}_{3}\right) \delta 43.5$.

(5S, 6R, 8R)-7,7-Dimethyl-2-aza-11-borapentacyclo[10.3.3.1 $\left.{ }^{6,8} \cdot 0^{2,11} \cdot 0^{5,10}\right]$ nonadecane (19). Into a round bottomed flask containing $7(3.05 \mathrm{~g}, 12.5 \mathrm{mmol})$ in $\mathrm{THF}(25.0 \mathrm{~mL})$ at $0{ }^{\circ} \mathrm{C}$ was added 17 (4.78 g, $50 \mathrm{mmol})$. The reaction mixture was stirred at $0{ }^{\circ} \mathrm{C}$ for $1 \mathrm{~h}$ and warmed up to $25{ }^{\circ} \mathrm{C}$ and stirred for $5 \mathrm{~h}$ at this temperature. The solvent was removed under vacuum and the residue was stirred at $200{ }^{\circ} \mathrm{C}$ for $12 \mathrm{~h}$. Distillation of the residue under high vacuum gave $7.72 \mathrm{~g}$ (52\%, bp $145{ }^{\circ} \mathrm{C}$ at 0.2 Torr) of 19. ${ }^{1} \mathrm{H}-\mathrm{NMR}\left(300 \mathrm{MHz}, \mathrm{CDCl}_{3}\right): \delta 0.69(\mathrm{~d}, J=11.8 \mathrm{~Hz}, 1 \mathrm{H})$, $1.15(\mathrm{~s}, 3 \mathrm{H}), 1.25$ (s, $3 \mathrm{H}), 1.39-1.53(\mathrm{~m}, 8 \mathrm{H}), 1.65-1.83(\mathrm{~m}, 8 \mathrm{H}), 2.00-2.02$ (m, $4 \mathrm{H}), 2.49$ (ddd, $J=14.9,6.2,2.3 \mathrm{~Hz}, 1 \mathrm{H}), 3.01-3.02(\mathrm{~m}, 1 \mathrm{H}), 3.10(\mathrm{dd}, J=8.6,6.8 \mathrm{~Hz}, 2 \mathrm{H}) ;{ }^{13} \mathrm{C}-\mathrm{NMR}$ $\left(75 \mathrm{MHz}, \mathrm{CDCl}_{3}\right) \delta 20.8(\mathrm{C} 12), 22.9(\mathrm{C} 17), 23.3\left(\mathrm{CH}_{3}\right.$ - attached to $\left.\mathrm{C} 7\right), 23.6$ (C 17), $26.4(\mathrm{C}$ 18), 27.3 (C 10), 27.3 (C 13), 29.9 (C 16), 30.3 ( $\mathrm{CH}_{3}$ - attached to $\mathrm{C}$ 7), 30.6 (C 4), 30.8 (C 2), 35.7 (C 9), 38.9 (C 7), 40.0 (C 19), 43.5 (C 8), 44.4 (C 5), 48.5 (C 6), 53.5 (C 3), 58.5 (C 1) ; ${ }^{11} \mathrm{~B}-\mathrm{NMR}\left(96 \mathrm{MHz}, \mathrm{CDCl}_{3}\right) \delta$ 47.0; MS: m/z (rel. abundance) 285 (6), 256 (7), 214 (5), 200 (15), 150 (61), 120 (23), 82 (72), 67 (100).

Reaction of 18 with $\mathbf{B H}_{3} \cdot \mathrm{SMe}_{2}$ : Into a round bottom flask containing $\mathrm{BH}_{3} \cdot \mathrm{SMe}_{2}(0.5 \mathrm{~mL}(10$ $\mathrm{M}), 5 \mathrm{mmol})$ in THF $(5.0 \mathrm{~mL})$ at $25^{\circ} \mathrm{C}$ was added $18(1.43 \mathrm{~g}, 5.0 \mathrm{mmol})$ in THF $(5.0 \mathrm{~mL})$. After $1 \mathrm{~h}$, a sample was taken for ${ }^{11} \mathrm{~B}$ NMR analysis suggesting the complete formation of a nitrogenand hydrogen-bridged diboryl species (two doublets at -6.9 and $-14.6 \mathrm{ppm}$ ). The mixture was stirred for $12 \mathrm{~h}$ and concentrated under vacuum. A sample was taken for ${ }^{1} \mathrm{H},{ }^{13} \mathrm{C},{ }^{11} \mathrm{~B}$ NMR and IR analysis, which indicated the formation of diboryl adduct $20 .{ }^{1} \mathrm{H}-\mathrm{NMR}\left(300 \mathrm{MHz}, \mathrm{CDCl}_{3}\right): \delta$ $0.77(\mathrm{~d}, J=9.2 \mathrm{~Hz}, 1 \mathrm{H}), 1.00-1.10(\mathrm{~m}, 2 \mathrm{H}), 1.13(\mathrm{~s}, 3 \mathrm{H}), 1.15-1.22(\mathrm{~m}, 4 \mathrm{H}), 1.23(\mathrm{~s}, 3 \mathrm{H})$, 1.30-1.40 (m, $1 \mathrm{H}), 1.44-1.48(\mathrm{~m}, 6 \mathrm{H}), 1.61-1.84(\mathrm{~m}, 8 \mathrm{H}), 1.93-2.12(\mathrm{~m}, 4 \mathrm{H}), 2.15-2.30$ (m, $1 \mathrm{H}), 2.42-2.55(\mathrm{~m}, 1 \mathrm{H}), 2.98-3.02(\mathrm{~m}, 1 \mathrm{H}), 3.14-3.16(\mathrm{~m}, 1 \mathrm{H}) ;{ }^{13} \mathrm{C}-\mathrm{NMR}\left(75 \mathrm{MHz}, \mathrm{CDCl}_{3}\right) \delta$ 19.7, 23.3, 23.7, 27.3, 27.9, 31.2, 32.1, 59.0 (ABBD ring moiety), 22.8 (CH3- attached to $\mathrm{C} 7$ ), 27.3 (C 3), 28.1 (C 4), $29.8\left(\mathrm{CH}_{3}\right.$ - attached to C 7), 30.4 (C 6), 38.5 (C 10), 39.6 (C 7), 42.6 (C 2), 43.5 (C 5), 46.1 (C 1), 54.0 (C 11); ${ }^{11} \mathrm{~B}-\mathrm{NMR}$ (96 MHz, $\mathrm{CDCl}_{3}$ ) $\delta-14.4$ (d, ${ }^{1} \mathrm{JB}-\mathrm{H}=116 \mathrm{~Hz}$, $\mathrm{B}$ attached to $\mathrm{C} 3$ ), -6.9 (d, $\left.{ }^{1} \mathrm{JB}-\mathrm{H}=106 \mathrm{~Hz}, \mathrm{ABBD} \mathrm{B}\right)$; IR (TF) 2500, 2440 (B-H stretch), 1605 (B-H-B and B-N-B stretch) $\mathrm{cm}^{-1}$.

Representative procedure for the asymmetric reduction of a prochiral ketone with $\mathrm{BH}_{3} \cdot \mathrm{THF}$ and heterocycles $9,13 \mathrm{~b}$ and 19

Into a round bottomed flask containing $\mathrm{BH}_{3} \cdot \mathrm{THF}(2.0 \mathrm{~mL}(1.0 \mathrm{M}$ in THF), $2.0 \mathrm{mmol}), 9 \mathrm{c}(0.04$ $\mathrm{g}, 0.02 \mathrm{mmol})$ and THF $(3.0 \mathrm{~mL})$ at $25^{\circ} \mathrm{C}$ was added acetophenone $(0.36 \mathrm{~g}, 3.0 \mathrm{mmol})$ dropwise. When the addition was complete, the reaction mixture was stirred for 5 min at $0{ }^{\circ} \mathrm{C}$. Water $(2$ $\mathrm{mL})$ and ether $(2 \mathrm{~mL})$ were added and the resulting two phases were separated. The organic phase was washed with water $(3 \times 1 \mathrm{~mL})$ and dried over magnesium sulfate. The organic phase was decanted, concentrated and Kugelrohr distilled to give $0.24 \mathrm{~g}(66 \%)$ of 1-phenylethanol. ${ }^{1} \mathrm{H}$ NMR (300 MHz, CDCl $) \delta 1.49(\mathrm{~d}, J=6.3 \mathrm{~Hz}, 3 \mathrm{H}), 2.21($ broad s, $1 \mathrm{H}), 4.87$ (q, J=6.3 Hz, 1 
$\mathrm{H}), 7.22-7.47(\mathrm{~m}, 5 \mathrm{H}) ;{ }^{13} \mathrm{C}-\mathrm{NMR}\left(75 \mathrm{MHz}, \mathrm{CDCl}_{3}\right) \delta 25.1$ (C 2), 70.3 (C 1), 125.3, 127.4, 128.4, 145.8 (o, p, $m, i$ of phenyl ring); IR (TF): $3340 \mathrm{~cm}^{-1} \mathrm{MS} \mathrm{m} / \mathrm{z}$ (rel. abundance) $122\left(\mathrm{M}^{+}\right.$, 16), 107 (66), 79 (100), 77 (59). This enantiomeric alcohol mixture was converted to the corresponding Mosher esters under the conditions described above, where a diastereomeric 55 : 45 mixture of $(R, R)$ - and $(R, S)$ - MTPA esters was observed as determined by integrating the ${ }^{1} \mathrm{H}$ NMR peaks of the sec-phenethoxy methyl group signals at 1.61 and $1.67 \mathrm{ppm}$, respectively as well as the ${ }^{13} \mathrm{C}$ NMR peaks of the methyl group signals at 21.6 and $22.0 \mathrm{ppm}$, respectively. Thus, the $\%$ ee of the alcohol obtained was determined to be $10 \%$. The configuration of the alcohol obtained was determined to be $R$ by comparing the NMR peaks of the diastereomeric Mosher ester mixture with the MTPA ester derived from authentic sample of $(S)-(-)$-sec-phenethyl alcohol.

\section{Representative procedure for the $\mathrm{BH}_{3}$ complexation experiments with (S)-Me-1, 9, 13 and} 19

A NMR tube was charged with $(S)$-Me-1 $(0.12 \mathrm{~g}, 0.43 \mathrm{mmol})$. Sodium borohydride-free $\mathrm{BH}_{3} \cdot \mathrm{THF}\left(0.37 \mathrm{~mL}(1.22 \mathrm{M}\right.$ in THF), $0.45 \mathrm{mmol})$ was added and $\mathrm{C}_{6} \mathrm{D}_{6}$ was added to reach a volume of $0.6 \mathrm{~mL}$ (the resulting inital concentration of $(S)$-Me-CBS and $\mathrm{BH}_{3} \cdot \mathrm{THF}$ is $0.72 \mathrm{M}$ and $0.75 \mathrm{M}$, respectively). A ${ }^{11} \mathrm{~B}$ NMR $\left(96 \mathrm{MHZ}, \mathrm{C}_{6} \mathrm{D}_{6}\right.$ ) was taken (coupled and decoupled) where the oxazaborolidine ring boron and the $(S)-\mathrm{Me}-\mathrm{CBS}-\mathrm{BH}_{3}$ complex $(\delta 36.3), \mathrm{BH}_{3} \cdot \mathrm{THF}(\delta-0.3(\mathrm{q}$, $J=103 \mathrm{~Hz})$ ) and $94(\delta-14.1$ (broad $\mathrm{q}), \mathrm{BH}_{3}$ group in $(S)-\mathrm{Me}-\mathrm{CBS}-\mathrm{BH}_{3}$ in a 85:15 ratio with respect of $\mathrm{BH}_{3}$. THF signal determined by integration) was observed. From the integration of the signals and the initial concentration $\left[(S)-\mathrm{Me}-\mathbf{1} \cdot \mathrm{BH}_{3}\right]=(0.85)(0.75 \mathrm{M})=0.64 \mathrm{M},[(S)-\mathrm{Me}-1]=$ $0.72 \mathrm{M}-0.64 \mathrm{M}=0.08 \mathrm{M},\left[\mathrm{BH}_{3} \cdot \mathrm{THF}\right]=(0.15)(0.75 \mathrm{M})=0.11 \mathrm{M}$, Keq. $=73 \mathrm{M}^{-1}$ and $\Delta \mathrm{G}^{\circ} \exp$. $=-2.54 \mathrm{kcal} / \mathrm{mol}$ (calculated from $\Delta \mathrm{G}^{\circ}=-\mathrm{RT} \operatorname{lnK}$ where $\mathrm{T}=298{ }^{\circ} \mathrm{K}$ and $\mathrm{R}=1.987$ $\left.\mathrm{kcal} /{ }^{\circ} \mathrm{K} \cdot \mathrm{mol}\right)$.

\section{Representative procedure for the reaction of propiophenone with $(R)-\mathrm{Me}-1$ and $9 \mathrm{~b}$}

An NMR tube was charged with $(R)-\mathrm{Me}-1\left(0.40 \mathrm{~mL}(1.0 \mathrm{M}\right.$ in toluene), $0.40 \mathrm{mmol})$ and $\mathrm{C}_{6} \mathrm{D}_{6}$ $(0.3 \mathrm{~mL})$. A ${ }^{11} \mathrm{~B}$ NMR was taken to check the oxazaborolidine boron chemical shift $(\delta 34.5)$. Propiophenone (0.06 g, $0.4 \mathrm{mmol}$ ) was added and ${ }^{11} \mathrm{~B}$ and ${ }^{13} \mathrm{C}$ NMR spectra were taken where no oxazaborolidine-ketone complex was observed to form. ${ }^{11} \mathrm{~B} \mathrm{NMR}\left(96 \mathrm{MHz}, \mathrm{C}_{6} \mathrm{D}_{6}\right) \delta 34.5$ (oxazaborolidine B); ${ }^{13} \mathrm{C}$ NMR $\left(75 \mathrm{MHz}, \mathrm{C}_{6} \mathrm{D}_{6}\right) \delta 199.1$ (C=O of pure propiophenone).

\section{Acknowledgements}

The support of the NIH-MBRS (SO6-GM08102), NSF (CHE9817550) and a NIH Pre-doctoral Fellowship (5 F31 GM18030-02) to JR are gratefully acknowledged. 


\section{References and Notes}

1. This work is dedicated to Professor Alfred Hassner on the occasion of his $70^{\text {th }}$ birthday.

2. Graduate student supported by the NIH Predoctoral Fellowship for Minority Students (5 F31 GM18030-02) and by the NIH-MBRS Program (SO6-GM08122)Reviews: (a) Wallbaum, S.; Martens, J. Tetrahedron: Asymmetry 1992, 3, 1475. (b) Deloux, L.; Srebnik, M. Chem. Rev. 1993, 93, 763.

3. (a) Corey, E. J.; Helal, C. J. Angew. Chem., Int. Ed. 1998, 37, 1986. (b) Corey, E. J. Pure Appl. Chem. 1990, 62, 1209. (d) Corey, E. J.; Bakshi, R. K.; Shibata, S. J. Am. Chem. Soc. 1987, 109, 5551. (e) Corey, E. J.; Bakshi, R. K.; Shibata, S.; Chen, C.-P.; Singh, V.; K. J. Am. Chem. Soc. 1987, 109, 7925. (f) Corey, E. J.; Shibata, S.; Bakshi, R. K. J. Org. Chem. 1988, 53, 2861.

4. Corey, E. J.; Cimprich, K. A. J. Am. Chem. Soc. 1994, 116, 3151.

5. Joshi, N. N.; Srebnik, M.; Brown, H. C. Tetrahedron Lett. 1989, 30, 5551.

6. Brown, J. M.; Lloyd-Jones, G. C. Tetrahedron: Asymmetry 1990, 1, 869.

7. Corey, E. J.; Loh, T.-P. J. Am. Chem. Soc. 1991, 113, 8966.

8. Parmee, E. R.; Tempkin, O.; Masamune, S. J. Am. Chem. Soc. 1991, 113, 9365.

9. Jones, T. K.; Mohan, J. J.; Xavier, L. C.; Blacklock, T. J.; Mathre, D. J.; Sohar, P.; Jones, E. T. T.; Reamer, R. A.; Roberts, F. E.; Grabowski, E. J. J. J. Org. Chem. 1991, 56, 763.

10. Brown, H. C.; Midland, M. M.; Levy, A. B.; Suzuki, A.; Sono, S.; Itoh, M. Tetrahedron 1987, 43, 4079.

11. Soderquist, J. A.; Najafi, R. M. J. Org. Chem. 1986, 51, 1330.

12. Ramachandran, P. V.; Gong, B.; Brown, H. C. J. Org. Chem. 1995, 60, 41.

13. Kolb, H. C.; VanNieuwenhze, M. S.; Sharpless, K. B. Chem. Rev. 1994, 94, 2483.

14. Midland, M. M.; Kazubski, A. J. Org. Chem. 1992, 57, 2953.

15. Evans, D. A.; Weber, A. E. J. Am. Chem. Soc. 1987, 109, 7151.

16. (a) Jego, J. M.; Carboni, B.; Vaultier, M. Bull. Soc. Chim. Fr. 1992, 129, 554. (b) Carboni, B.; Vaultier, M. Bull. Soc. Chim. Fr. 1992, 129, 554. (c) Salmon, A.; Carboni, B. J. Organomet Chem. 1998, 567, 31.

17. Girard, S.; Robins, R. J.; Villiéras, J.; Lebreton, J. Tetrahedron Lett. 2000, 41, 9245.

18. Schlessinger, H. I.; Ritter, D. M.; Burg, A. B. J. Am. Chem. Soc. 1938, 60, 2297.

19. Dobson, J.; Schaeffer, R. Inorg. Chem. 1970, 9, 2183.

20. Köster, R.; Seidel, G. Liebigs Ann. Chem. 1977, 1837.

21. Corey, E. J.; Azimiohara, M.; Sarshar, S. Tetrahedron Lett. 1992, 33, 3429.

22. (a) Soderquist, J. A.; Medina, J. R.; Huertas, R. Tetrahedron Lett. 1998, 39, 6119. (b) Soderquist, J. A.; Huertas, R.; Medina, J. R. Tetrahedron Lett. 1998, 39, 6123. (c) Brown, H. C.; Bhaskar Kanth, J. V.; Zaidlewicz, M. J. Org. Chem. 1998, 63, 5154. (d) Brown, H. C.; Zaidlewicz, M.; Dalvi, P. V. Organometallics 1998, 17, 4202. (e) Brown, H. C.; Kanth, J. V. B.; Zaidlewicz, M. Organometallics 1999, 18, 1310. (f) Brown, H. C.; Kanth, J. V. B.; 
Dalvi, P. V.; Zaidlewicz, M. J. Org. Chem. 1999, 64, 6263. (g) Brown, H. C.; Kanth, J. V. B.; Dalvi, P. V.; Zaidlewicz, M. J. Org. Chem. 2000, 65, 4655.

23. Brown, H. C.; Midland, M. M.; Levy, L. V.; Kramer, G. W. Organic Syntheses via Boranes; Wiley-Interscience: New York, 1975.

24. Forster, M. O.; Fierz, H.E. J. Chem. Soc. 1988, 93, 1865.

25. Sutowardoyo, K. I.; Emziane, M.; Lhoste, P.; Sinou, D. Tetrahedron 1991, 47, 1435.

26. Foelsche, E.; Hickel, A.; Hönig, H.; Seufer-Wasserthal, P. J. Org. Chem. 1990, 55, 1749.

27. Ittah, Y.; Sasson, Y.; Shahak, I.; Tsaroom, S.; Blum, J. J. Org. Chem. 1978, 43, 4271.

28. This diol was made in a $89 \%$ ee by the Sharpless Asymmetric Dihydroxylation procedure: Crispino, G. A.; Jeong, K.-S.; Kolb, H. C.; Wang, Z.-M.; Xu, D.; Sharpless, K. B. J. Org. Chem. 1993, 58, 3785.

29. This diol was made in a $>99.5 \%$ ee by the Sharpless Asymmetric Dihydroxylation procedure: Sharpless, K. B.; Amberg, W.; Bennani, Y. L.; Crispino, G. A.; Hartung, J.; Jeong, K.-S.; Kwong, H.-L.; Morikawa, K.; Wang, Z.-M.; Xu, D.; Zhang, X.-L J. Org. Chem. 1992, 57, 2768.

30. Oi, R.; Sharpless, K. B. Tetrahedron Lett. 1991, 32, 9 